\title{
Research on Self-portrait Artistic Creation
}

\author{
Hanying Jiang, Xianfei Liang, Guoying Chen \\ Lushan College of Guangxi University of Science and Technology, Liuzhou, Guangxi, 545036, \\ China
}

\begin{abstract}
Keywords: self-portrait, artistic creation
\end{abstract}
\begin{abstract}
Self-portrait is the mirror image of the mind, it is the artist's exploration of the inner self and it is the self-portrait portrait for artist. The artist understands himself through this way. The development of self-portrait art actually reflects the development process of the western art history. In different periods, the different art schools self-portrait art presents different style and the style is as an independent art form, showing a variety of artistic language forms, it is the portrayal of the artist's self-examination. The study of self-portrait art has a more profound practical significance.
\end{abstract}

\section{The development of self - portrait art in Western art}

Self-portrait art as an independent form of art has gone through three centuries long evolution, never independent to independent, Western self-portrait and landscape painting, but also from the religious paintings, portraits gradually separated. Self-portrait is a free art, without any utilitarian and commercial, the artist's self-awareness and self-interest is one of the reasons why self-portrait art is enduring, the Renaissance is relatively relaxed human environment, the people themselves The rise of the status of the artist to enhance the status of their desire to become more and more intense, this period since the portrait art despite the independence, but still a true portrayal of the artist's self-image, reflecting the artist's self-consciousness Awakening. This time the painter's selfportrait is humble and shy when presenting self-mirroring. They often through the hidden, alternative, dress themselves and other ways to reflect their presence and presence. In the Renaissance, especially in the middle and late period, with the change of the social status of the painter and the improvement of self-consciousness, the artist's self gradually emerged from the role of the attendant as a religious and historical story, and depicts the independent self portrait The Independent self-portrait began to appear. From the late 14th century to the 16th century, the artist's self-portrait was from scratch, from the inconspicuous corner of the work of art to the centre of the picture, and eventually developed into an independent art form, which in itself embodies the artist's self-existence attention. Self-portrait as a special genre of the portrait is able to impress the viewer, is that it is a unique artistic charm to create a typical sense of the self-inner world and personality characteristics.

Self-portrait of the bud and the Renaissance advocated by the spirit of humanism are inextricably linked. From the worship of divinity to the attention of human nature, human values are fully affirmed, the spread of humanistic ideas to promote the awakening of the artist's self-consciousness and began to seek self-existence, began to hide their own image in the corner of the screen, with hidden self- Expressed their understanding of self, reshaping the ideal of self. Renaissance in the 
field of art also set off the revival of ancient Greece, the ancient Roman art movement and this period of painting mostly borrowed the form of classical art to express the desire for humanism. In the self-portrait, this period of artists focus on the performance of the image of the "ideal me". "Athenian Academy", Rafael painted Michelangelo as the image of thinker Heraclitus, depicting Da Vinci as the image of the philosopher Plato. He will be with their own image of the artist as the ancient sage, philosophers of the prototype creation techniques, suggesting that the artist and the ancient philosophers of the mind in the same vein of the same strain.

Realistic painting, whether in the subject matter or in the characterization of the show to the real life of the return, in the era of change, the capitalist budding and industrialization of the process opened up a new era, art aesthetic concept with the change, the art is not And then confined to the Renaissance stressed the concept of harmony, ideal and beauty, advocate breaking the harmony, emphasizing the real, natural, personality. Realistic self-portraits represented by Kurbee show a realistic picture of the ideal and realistic image of the world. Artists no longer add themselves to the story of religious paintings or historical themes, but to identify themselves as a person in a secular society, through the real picture depicting to reflect self-existence, to confirm the image and identity. During this period the artist did not have to be resembled by the Renaissance artist's authority over the feudal church, but only to conceal or replace himself in the works of religious themes, and the artist had a relatively free creation environment. In the "self-portrait of the dog," the artist will blend himself into the reality of nature, self-confident proudly raised his head, dress, no modification, seem simple and natural, portrayed as a rebellious, free youth Image, Dumier in the "painter in the studio" will be painted as an ordinary artist, the picture shows the life of the painting in the ordinary scene. Realism has given up the pursuit of classicalism to idealism, and the self-portrait of this period is a typical mirror of the return to reality.

After the 20th century, the industrial revolution brought about the rapid development of economy, science and technology, social development brought new ideological liberation, in the field of art, "painting is not a natural servant", "painting language independent value", " Art and art "and so on, lay the theoretical foundation for artistic creation. Artists are beginning to realize that the old order, the concept is no longer in line with the characteristics of the times and art is no longer an absolute record of the true nature. But also began to leave the religious control, gradually self-contained. Such as Chagall's self-portrait is full of juvenile childlike beauty, with fantastic colour and poetic narrative symbol characteristics, Dali's self-portrait more performance dream subconscious, with surrealism; Bacon's self-portrait using deformation, distortion, exaggeration. The self-portrait art of this period is more concerned with the expression of the subjective world, and each artist has his own understanding of the art of the new period, and the artist is free to explore the individual language that expresses himself. They focus on the pursuit of artistic forms, with purely painting language to express artistic ideas, fully demonstrated the visual form of beauty. They "constantly unconventional, constantly innovation, and continue to enlarge themselves, publicity personality, to express their own style."

In the second half of the 20th century, with the rapid development of science and technology and economy, the West quickly entered the post-industrial society of the information age. The end of 
the world war, so that people away from the suffering brought by the war, and accelerated the exchange between the people; the rapid development of the economy, so that people's living consumption is increasing, and accelerate the market of goods; The rapid development and expansion of the information network, pop art, new art, occasional art, earth art, super realism, wave art, performance art, conceptual art and so on the pace of the times have appeared, constitute a colourful hybrid Artistic pattern. Under the guidance of this value concept, postmodern art has shown a high degree of freedom in the process of creation and criticism. Andy Warhol is the master of American pop art and is also a typical representative artist of the whole Western postmodern art, Warhol and his art as a "mirror" from a certain angle reflects the existence of Western post-modern art. Warhol created a number of "self-portraits" in life, in the performance of self-works, Warhol established artistic concepts and artistic language, in the West and even the world is widely disseminated. Warhol incorporates his own image into the current cultural context by making a variety of means: such as making self-portraits, self-portraits, making and participating in film shows or even buying TV channels for a period of time in the public view So that the artist's own symbolization, identification and conceptualization. The artist symbolizes himself and replaces his own reality with symbols.

\section{The evolution of self - portrait artistic expression}

Self-portrait is the artist's most direct way to understand the self, the artist through the selfappearance, clothing, environment, etc. can convey the artist's identity and ideals, the picture solidified instantly record their living environment background and state, is the painter's life experience monologue. The Dürer's self-portraits are gorgeous and the landscapes are meticulous. Rafael's self-portrait looks confident and expresses a strong self-concept. At this time, self-portrait art emphasizes self-appearance, dress, environment and so on, is the artist's identification of selfidentity, the artist needs to "know the self", generally concerned about the "I am who" problem, self-portrait of the artist's life background and Survival state, reflecting the specific period of the specific environment of the artist's ideal of life, is the artist "self-talk" personal description and expression, used to record the self-portrait of life is more like an autobiographical diary. This period reflects the painter's understanding of his own social role and cultural role.

The traditional portrait of the artist's personal feelings is subtle and restricted, and self-portrait is a free art, which infiltrate more private emotions and imagination, the artist can directly express their emotional experience, ideals and beliefs and inner world, The self-inner feelings into the canvas to complete the emotional catharsis, so that the viewer into their inner world, self-portrait to complete the artist's spiritual demands, is the artist's main psychological and emotional externalization. The viewer sees the pain and Perseverance, Carlo's "self-portrait" in a stubborn gesture to challenge the life cannot afford the weight, expression of grief and despair, works "deer" to draw himself as a wounded deer to metaphor in reality sadness, strong subjective feelings "I painted myself because I was often lonely because I was the most familiar subject." The work is full of rich reading, Self-portrait is more like a life log, record her short life in the joys and sorrows, including the existence of life and the value of life profound thinking, and thus have the formal 
meaning, self-portrait to complete the interpretation and examination of the self. Similarly, Van Gogh "wrapped bandage self-portrait" to show a spirit of the edge of the collapse of the inner anxious state, showing the peerless lonely and helpless, it can be said that Van Gogh's strong inner feelings appeal to the pen, works with a strong psychological The Munch restless strokes almost let the souls of the soul flowing out of this period from the portrait with colour and lines to vent emotions, breaking the real reality of the mechanical imitation, into the inner world, concerned about the inner spirit, from the reproduction of the visual image of the real The inner spirit of the subject, the inner psychological expression. Self-portrait creation as a spiritual solace, completed the inner self-talk.

On the other hand, self-portrait art has a strong subjective colour, different artists reflect the works of different aesthetic taste and artistic style is different. On the other hand, self-portrait art is a kind of image. If the Renaissance self-portrait focuses on the true reproduction of life in the typical, then the plug is still represented by the post-impression, fauvism, cubism and other schools in the form of expression is more free use of colour and lines, emotional expression While reflecting the different artistic ideas. The self-portrait of this period is more deviated from the tradition, the reality of the desalination of life, in the expression of the artist's own feelings, inner world at the same time, more emphasis on the art of language form of exploration. Cezanne's "selfportrait" with a cool brush to analyze the inner structure of the characters, to subvert the traditional perspective, the simplification of self-modeling and plane processing to make the screen more orderly, rational, rational analysis of the character structure so that self-portrait is no longer limited In the portrait itself, Cezanne's "self-portrait" completed the exploration of the form of the New Art language. Similarly, the Cuban representative Picasso in different periods of self-portrait performance practices are different from the initial reproduction of real life to the use of Cubism analysis language to interpret the heart, breaking the conventional visual experience, reflecting the artist's view of the language of art language.

Self-image as a symbol of the times to become the theme of creation, with self-portrait to express the subject of self-ideas, and this right to use the social criticism activities, through the self-image of the digestion, change to get more free art space and this stage, self-portrait art completed another turn. The self-image has the broad sense and becomes the tool for the artist to judge the social reality. The artist completes the dialogue with the outside through self-portrait, strengthens the selfportrait expression, extends the spiritual connotation of the self-portrait work, and enhances the value of the self-portrait in contemporary art. Self-portrait and thus have a "symbolic, conceptuality", this "cynical" self-portrait art of social reality concerns far more than the self-image of the attention, the picture of "I" represents the specific ethnic groups of psychological and mental state, In fact, the work has not been too much self-expression of the composition, but with the "digestion" of the self-image of self-feelings with the existence of social reality, the expression of contemporary mental state of life thinking, expression of the artist's social reality view.

Self-portrait art as a unique form of portraiture, as an ancient painting theme style, in the contemporary have a new presentation and performance content, from the description of "external reality" to express the "internal reality" to complete the "material self" To the "spiritual self" and 
then to the "social self" evolution, including the artist's art, on the self, the different views of society, the purpose of creation by the attention of personal emotional experience into the social reality, the form of painting on the innovation zone To the people's thinking of aesthetics, with independent artistic value, the study of self-portrait art for the creation of the painting on the shelf provides a positive reference.

\section{References}

[1] Xu Gan. "Portrait" is "depiction" - modern Western portraits. World Art, 55(12), pp.68-70, 2011

[2] Lin Dayi. The history of Western self-portrait art. Beijing: China Academy of Art, 8 (5), pp.8791, 2013

[3] Zhang Pengfei. Mirror monologue - self-portrait in the inner world of art America and the times, 12(10), pp. 18- 20, 2012

[4] Wang Yuhui. Analysis of the spirit of Western self-portraits. Jining: Qufu Normal University, 9(6), pp.58- 61, 2011

[5] Yuan Yue. Analysis of the artist's self-portrait. Hunan: Hunan Normal University, 8(4), pp.8587, 2014 